\title{
ACADEMIC SELF-CONCEPT ON BULLY VICTIMS IN EARLY ADOLESCENT
}

\author{
Anne Cintya Afriliani*, Aat Sriati, Efri Widianti \\ Fakultas Keperawatan, Universitas Padjadjaran, Gedung. L1 Lt. 2, J1. Raya Bandung - Sumedang No.KM. 21, \\ Hegarmanah, Jatinangor, Kabupaten Sumedang, Jawa Barat, Indonesia 45363 \\ *anneafriliani@gmail.com
}

\begin{abstract}
Bullying that occurs in schools have negative impacts on victims rather than perpetrators. Bullying has an influence on the social adjustment of the victims that affects school achievement. In education, academic self-concept has an important role in the achievement of student learning in school and help students respond to bullying behavior. The aim for this study was to identify the academic self-concept on bully victims in early adolescent that consist of academic, social, and self-regard. This research was a quantitative descriptive research. The population in this research were all bully victims from grade 7 and 8 , the sample technique used was total sampling with 91 respondents. Data were taken by using academic self-concept instrument from Sriati which consist of 45 statements using likert scale with validity value 0,339-0,761 and reliability 0,952. The academic self-concept analyzed by mean of both total and each dimension. The results were shown by percentage. The results of this study indicated that some respondents i.e. 47 people $(51,6 \%)$ had positive academic self-concept and about 44 people $(48,4 \%)$ had negative academic self-concept. In academic dimension, 48 people $(52,7 \%)$ had positive aspect, social dimension mostly 55 people $(60,4 \%)$ had positive aspect, and self-regard most of 51 people $(56 \%)$ had positive aspect. The positive academic self-concept and negative academic self-concept on bully victims in early adolescents were not much different.
\end{abstract}

Keywords: academic self-concept; adolescent; bullying

\section{INTRODUCTION}

Adolescents are particularly vulnerable to psychosocial problems (Febriana et al., 2015) because they are undergoing not only physical but emotional, cognitive, and psychological changes (Agustiani, 2009). In addition to these changes, adolescents are also expected in forming their identity in order to complete their developmental stages that are influenced by the environment (Agustiani, 2009).

In expanding their identity, adolescents have the need and desire to be accepted and recognized in a particular group. The success of adolescents in carrying out their developmental tasks will affect whether or not he or she is in carrying out the task of further development (Agustiani, 2009). The changes in adolescent's self as well as the increasing pressure and stress of the environment makes them easily deal in conflicts such as bullying (Febriana et al., 2015; Wu et al., 2016). In Indonesia, data from KPAI mentioned that since 2012-2015, 87\% of children and teenagers were experiencing bullying (Febriana et al., 2015) and $40 \%$ of cases occur in schools (UNICEF, 2015). KPAI also noted from 2011-2014 cases of bullying in schools was ranked the top who complained the community (Herdyanti \& Margaretha, 2016). As a result of bullying behavior, the impact felt on the victim is more severe than the perpetrators (Aviani, 2015, Wolke \& Lereya, 2015). Not only have physical effects but also have negative effects on mental health and psychological well-being of victims (Wu et al., 2016; Raskauskas, 2010).

In education, bullying has an influence on academic self-concept in which the impact of bullying is adolescent's deterioration of learning achievement in school (Herdyanti \& Margaretha, 2016; Raskauskas, 2010) and according to Baek and Yoo (2017) and Jenkins (2015) achievement in schools is related to academic self-concept because it is directly affects learning process, learning achievement, and student's expectation towards their future. Many studies reveal the negative impact of bullying behavior on school achievement. Victims of bullying in schools have poor social adjustment, which causes the victim to be afraid to go to school so that the victim does not want to go to school, withdraws from the society, trouble concentrating while studying, resulting in 
decreased learning achievement (Trigg in Dwipayanti \& Indrawati, 2014).

Herdyanti \& Margaretha (2016) and Raskauskas (2010) stated that children who get harsh treatment at school will usually be lazier to go to school and their academic performance tends to go down, they also stated that the involvement of students with bullying as victims is highly leaven to their academic competence. Kibriya, Xu, \& Zhang (2016) also derived from their research that there was an average drop of 18.5 on the academic grade of junior high school students who were experiencing bullying.

Academic self-concept is a perception, thought, feeling, and appraisal of a person's academic ability. Self-concept is one of the things that affect the process of identity formation in adolescents because they mostly depend on the environment and relationship with others in the society (Agustiani, 2009) and when teenagers are faced with situations like bullying it can affect the formation of their self-concept because the judgment or opinion of others towards him or her influences the formation of self-appraisal.

Nurses as resources that play a role in the implementation of the mental health program from Puskesmas, have a role in the efforts of preventive, promotive, and rehabilitative (Permenkes, 2014). In preventive efforts, nurses may involve in the School Health Unit (UKS) to get a screening for victims of bullying where they are a group of risks that, if not addressed or handled quickly and appropriately, it can have an impact on their physical and psychological problems. One of the psychological impacts that need to be considered is the negative of academic selfconcept in bullying students that can lead to the deterioration in achievement and grades in schools.

Seeing many negative impacts of bullying on bully victims against the deterioration in school achievement for adolescents, it is the basis of this research to see the academic selfconcept on bully victims. The purpose of this study was to perceive the academic self- concept of bully victims in adolescent using a quantitative descriptive research design.

\section{METHOD}

This research was conducted in January 2018 using a quantitative descriptive research design to know academic self-concept on bully victims. The population in the research were all bully victims from grade 7-8. The sampling technique used was total sampling with the number of research samples were 91 students of bully victims.

Data were collected using the instrument of academic self-concept from thesis of Sriati (2010) consist of 45 statements with 3 dimensions of academic, social, and selfregard/presentation of self. Validity test results were in the range of $0.339-0.761$. Reliability of this instrument were using Alpha Cronbach method with the reliability coefficient of more than or equal to 0.7000.952 (high reliability). Data were collected in school and described with frequency distribution.

To collect data, researcher was looking for bully victims, using inform consent, and then distributed the questionnaires of academic self-concept. After the data were collected, the researcher performed data processing and was analyzed using the mean value as the measure. All data in this research was categorical data, so univariate analysis was done using frequency distribution. Univariate analysis was performed to describe each of the 3 dimensions and total of 3 dimensions of academic self-concept. The results of univariate analysis data were described in terms of frequency and percentage.

\section{RESULTS}

The characteristic data of respondents were seen from age and gender (Table 1) as well as from the type of bullying and experienced by the victim (Table 2). Table 1 shows from 91 bullied students of SMP Negeri 2 Cileunyi, most of the students were 13 years old $(60.4 \%)$. Almost half of students were female, 50 students $(54.9 \%)$. 
Table 1.

Characteristics of Bully Victim Respondents $(\mathrm{n}=91)$

\begin{tabular}{lccc}
\hline & Characteristic & f & $\%$ \\
\hline Age & & & \\
& 12 year old & 12 & 13.2 \\
& 13 year old & 55 & 60.4 \\
\multirow{3}{*}{ Gender } & 14 year old & 24 & 26.4 \\
& & 24 & 26.4 \\
& Male & 41 & 45.1 \\
& Female & 50 & 54.9 \\
\hline
\end{tabular}

Table 2.

Characteristics of Bully Victim Respondents by Type of Bullying ( $\mathrm{n}=91$ )

\begin{tabular}{lcc}
\hline \multicolumn{1}{c}{ Type of Bullying } & $\mathrm{f}$ & $\%$ \\
\hline Teasing & 31 & 34.1 \\
\hline Exclusion & 7 & 7.7 \\
\hline Physical & 5 & 5.5 \\
\hline Teasing and Harassment & 4 & 4.4 \\
\hline Teasing and Exclusion & 24 & 26.4 \\
\hline Teasing and Physical & 20 & 22 \\
\hline
\end{tabular}

Table 3.

Academic self-concept in Bully Victims $(\mathrm{n}=91)$

\begin{tabular}{lccc}
\hline & Academic Self Concept & $\mathrm{f}$ & $\%$ \\
\hline Positive & 47 & 51,6 \\
Negative & 44 & 48,4 \\
\hline
\end{tabular}

Table 4.

Academic self-concept in Each Dimension in Bully Victims $(\mathrm{n}=91)$

\begin{tabular}{lccc}
\hline \multicolumn{2}{c}{ Academic Self Concept } & f & $\%$ \\
\hline Academic & Positive & 48 & 52.7 \\
& Negative & 43 & 47.3 \\
Social & Positive & 55 & 60.4 \\
& Negative & 36 & 39.6 \\
Self-regard/presentation of self & & 56 \\
& Positive & 51 & 44 \\
\hline
\end{tabular}

Table 5.

Academic self-concept Based on Crosstab in Bully Victims $(\mathrm{n}=91)$

\begin{tabular}{ccccccc}
\hline Academic & \multicolumn{2}{c}{ Academic } & \multicolumn{2}{c}{ Social } & \multicolumn{2}{c}{ Self-regard / Presentation of self } \\
\cline { 2 - 6 } self-concept & $(+)$ & $(-)$ & $(+)$ & $(-)$ & $(+)$ & $(-)$ \\
\hline Positive & 40 & 7 & 42 & 5 & 42 & 5 \\
& $(85.1 \%)$ & $(14.9 \%)$ & $(89.4 \%)$ & $(10.6 \%)$ & $(89.4 \%)$ & $(10 \%)$ \\
Negative & 8 & 36 & 13 & 31 & 9 & 35 \\
& $(18.2 \%)$ & $(81.8 \%)$ & $(29.5 \%)$ & $(70.5 \%)$ & $(20.5 \%)$ & $(79.5 \%)$ \\
\hline
\end{tabular}


Table 6.

Academic self-concept Based on Types of Bullying in Bully Victims ( $\mathrm{n}=91)$

\begin{tabular}{lcc}
\hline \multirow{2}{*}{ Type of Bullying } & \multicolumn{2}{c}{ Academic self-concept } \\
\cline { 2 - 3 } & Positive & Negative \\
\hline Teasing & $28(30.8 \%)$ & $3(3.3 \%)$ \\
Exclusion & $6(6.6 \%)$ & $1(1.1 \%)$ \\
Physical & $1(1.1 \%)$ & $4(4.4 \%)$ \\
Teasing \& Harassment & $2(2.2 \%)$ & $2(2.2 \%)$ \\
Teasing \& Exclusion & $5(5.5 \%)$ & $19(20.4 \%)$ \\
Teasing \& Physical & $5(5.5 \%)$ & $15(16.5 \%)$ \\
\hline
\end{tabular}

In Table 2, the type of bullying: teasing or mocking with the verbal was more experienced in the victims of 31 people (34.1\%) and there were 24 people $(26.4 \%)$ experienced bullying: teasing (verbal) and exclusion (exclusion) simultaneously. In Table 3 and Table 4 the results show that more than half of respondents, amounting to 47 people had positive academic self-concept with percentage of $51.6 \%$ and more than half of teenage victim of bullying that were 48 people $(52.7 \%)$ had academic dimension positive, most of which were 55 people (60.4\%) showed positive social dimension, and more than half $(56 \%)$ had positive selfregard dimension.

Table 5 show the results of crosstab, it seen that of 47 adolescents who were bullied that had positive academic self-concept also had a negative dimension on him/herself as well as with adolescents who were bullied who had negative academic self-concept, also had a positive dimension on him/herself. In adolescent who were bullied who had positive academic self-concept, 9 people $(19.1 \%)$ had negative academic dimension, 5 people $(10.6 \%)$ had negative social dimension, and 5 people $(10 \%)$ had negative self-regard. Of the 44 adolescents who were bullied with negative academic self-concept, $2(4.5 \%)$ had positive academic dimension, $13(39.5 \%)$ had positive social dimension, and 9 people $(20.5 \%)$ had positive self-regard.

It can be seen from Table 6, adolescents who had positive academic self-concept experienced teasing as bullying type with 28 people $(30.8 \%)$ than other types. Whereas in adolescents who had negative academic self- concept had more experienced in teasing \& exclusion as bullying types simultaneously with 19 people $(20.4 \%)$.

\section{DISCUSSION}

Adolescents who have positive academic selfconcept will look more optimistic, confident, positive toward everything. They have belief in self ability especially in learning as learners. The positive academic self-concept is very useful in the development of education and is often considered as an important thing to support the performance of learning in the present and future (Bong \& Skaalvik, 2003; Lösch et al. 2017; Samiroh \& Muslimin, 2015).

The negative of academic self-concept is indicated by a negative assessment of himself, feelings of self-confidence, unaware and knowing ability possessed and unable to use it, less motivation, especially in terms of learning and to get academic achievement in school. Adolescents with negative academic self-concepts are usually shown with low and unsatisfactory learning outcomes; they also withdraw from society, trouble in managing attention, difficulty concentrating on tasks, and laziness to go to school (Houbre et al., 2010; Herdyanti \& Margaretha, 2016; Raskauskas, 2010).

Jenkins (2015) says that academic selfconcept is an important variable in supporting achievement in school. Her research showed that there was a relationship between bully victims with low academic self-concept, resulting a decrease in school achievement. It is also assisted by other studies which suggest that bully victims have negative academic 
self-concept (Houbre et al., 2010; Herdyanti \& Margaretha, 2016).

In contrast to a study conducted by Jenkins, in this study, bullied adolescents had more positive academic self-concept than negative ones (Table 3), the possibility of it occurring due to several factors that affect such as the environment, the relationship with family and peers, relationships with teachers, then gender, success from interpersonal experience, and learning achievement during school.

Some training and character education by BK (Bimbingan Konseling) teachers, English lessons with students apply it every day, art and music activities, and extracurricular activities followed by students, such activities as disclosed by Agustiani (2009) and Baek and Yoo (2017) can be an interpersonal experiences to create positive feelings for oneself so that they are aware of their abilities and potentials because adolescents in their development stages want to be accepted and acknowledged by those around them and will try to be always in the situations that help them appreciate themselves positively and avoid those who make them feel negative about themselves. The belief of bully victims that they have the ability and able to get achievement in school either through the program held by the school will give a positive influence on the academic selfconcept in which directly assist them in the formation of identity and fulfill its development tasks.

Song and Hattie (1992) reveals that the significant others or people who feel the most important and close in one's life are family and peers, have an important role in the formation of academic self-concept. The result of the research seen in Table 4 shows that $60.4 \%$ of bully victims had positive social dimension. This is also in line with the theory expressed (Wilson et al., 2014; Jenkins, 2015; Marsh \& Martin, 2011) that the academic self-concept is an appraisal of oneself in his/her academic abilities that coincide with his/her social environment such as peers, parents, and teachers.
Baek and Yoo (2017) who explained that the influence of friends in school is one of factor that supports adolescents' academic selfconcept because in general, adolescents are strongly influenced by the social environment. The interaction of teenagers who get bullied along with their thoughts and emotions relies heavily on their friends as a place to solve the problems they are facing at the moment and as a place to ask for help. With the recognition and acceptance of their friends, bullied teenagers will feel that they are valuable, accepted, and confident of own potential that they have not realize due to the behavior of bullying itself. Ma et al. (2009) also revealed that teenagers who are supported by their closest friends, usually have satisfactory grades and achievements compared to those who do not get support.

Family or parents is an important factor in improving academic self-concept in adolescents. Research Ma et al. (2009) says that support from parents can improve academic self-concept because family as the closest source to teenagers in whom will always encourage them to keep trying and thinking positively by always improving their skills and potential. Matovu (2012) also said with the existence of home environment components that are safe, comfortable, giving rewards and direct parenting can help maintain the academic self-concept in adolescents.

Another factor that also affects academic selfconcept is teacher. Ma et al. (2009) reveals a school climate that provides a sense of security and comfort with a good relationship the teacher and gives individuals the opportunity to express themselves academically through the involvement of activities at school without comparable with peers also helps in improving academic selfconcept.

In addition to those factors, accomplishment that have been achieved in schools also affect how teenagers assess and see their abilities. Song and Hattie (1992) sees academic through its achievements and abilities in school. Bully victims who already have 
accomplishments that they think are satisfactory, and have the ability or effort in learning can maintain its achievement without seeing the bullying that occurs and that is felt on them.

This result is consistent with a study conducted by Juvonen \& Wang (2011) stated that bully victims who have good learning achievement and have skills and capability at school, will assume that bullying will not threaten themselves in the process of achievement or study in school and can perform its role as students in studying and learning.

The statement about the achievement and ability of a teenager is also expressed by Song \& Hattie (1992) and Matovu (2012) showed that the ability to show the extent to which the individual believes that he/she is able to achieve something while achievement related to beliefs or judgments about an achievement that already actual or happen in themselves so that teenagers who experience problems such as bullying, if they have the ability and good achievement in themselves, learning achievement will not be disturbed.

The individual's self-appraisal in terms of both physical and self-confidence also influences academic self-concept. According to Song \& Hattie (1992) selfregard/presentation of self has two categories of physical appearance and self-belief. A study conducted by Kaukiainen et al. (2002) said that bully victims usually consider themselves low and feel their physical appearance is lacking. This can be reflected in adolescents who have negative academic selfconcept because they look down on themselves and have poor judgments about their physique, they consider themselves unattractive and lack self-confidence. Houbre et al. (2010) also said that bullying leads to a decrease in academic self-concept, one of them because the victim is often associated with physical appearance.

Gender is also one of the things that can affect adolescents in establishing their academic self-concept. From the results of this study, it can be seen in Table 1, there were 50 girls (54.9\%) who experienced bullies. This is in contrast with study conducted by Hoglund (2007) who argued that gender or sex influences how bullying behavior can affect the learning process in school.

According to Hoglund (2007), teenagers who get unpleasant behavior such as bullying, affect internalization problems within them, thus threatening their confidence in friends and high levels of awareness of the environment. These threats are considered to be quite problematic especially in girls because their orientation is quite high on issues with friends and the surrounding environment. Nurses, especially school health nurses as holistic health providers, can undertake special care or concern to the victims with the mental health community's nursing approach so that the impacts arising from bullying can be well anticipated.

Limitations in this study that the results of research depend on the honesty of respondents in answering each item statement. Researchers also did not see data related to long-term derivation in school's achievement and did not see how long bullying occurred in the respondents.

\section{CONCLUSION}

In this study, it can be concluded that the results of positive and negative academic selfconcepts on bully victims were not so far. This could occur because of the different responses acceptance due to bullying that occurred in students and the involvement of factors that could affect academic selfconcept. Overall, this has answered the purpose of the research, which is to see how the academic self-concept of bully victims is based on different dimensions.

For further study, researchers can conduct a correlation study to see between the types of bullying and academic self-concept in adolescents, and can see the type of bullying that most often occurs at each stage of adolescent's development. 


\section{REFERENCES}

Agustiani. Psikologi Perkembangan: Perkembangan Ekologi Kaitannya dengan Konsep Diri dan Penyesuaian Diri pada Remaja. Bandung: PT. Refika Aditama; 2009.

Aviani, H. M. (2015). Tubuh-Tubuh Intimidasi. Jurnal Tingkat Sarjana Seni Rupa No. 1, (1), 1-9.

Baek, S., Yoo, H., \& Baek, S. (2017). Issues in Mental Health Nursing Ecological Factors Influencing Emotional / Behavioral Problems and Self-Concept in Adolescents from Low-Income Families in South Korea Ecological Factors Influencing Emotional / Behavioral Problems and Self-Concept in Adolescents from Low-Income Families in South Korea. Issues in Mental Health Nursing, O(0), 1-9. https://doi.org/10.1080/01612840.2017. 1325949

Bong, M., \& Skaalvik, E. M. (2003). Academic Self-Concept and SelfEfficacy: How Different Are They Really? Educational Psychology Review, 15(1), 1-40.

Dwipayanti, I. A. S., \& Indrawati, K. R. (2014). Hubungan Antara Tindakan Bullying dengan Prestasi Belajar Anak Korban Bullying pada Tingkat Sekolah Dasar Ida Ayu Surya Dwipayanti dan Komang Rahayu Indrawati. Jurnal Psikologi Udayana, 1(2), 251-260.

Febriana, B., Poeranto, S., Kapti, R. E., Ilmu, F., Universitas, K., Sultan, I., Brawijaya, U. (2015). Pengaruh terapi kognitif terhadap harga diri remaja korban bullying. Jurnal Ilmu Keperawatan Universitas Islam Sultan Agung, 4(1), 73-84.

Hattie, John. (1992). Self-Concept. New York: Psychology Press.

Herdyanti, F., \& Margaretha, M. (2016). Hubungan Antara Konsep Diri Dengan Kecenderungan Menjadi Korban
Bullying Pada Remaja Awal. Jurnal Psikologi Undip, 15(2), 92-98.

Hoglund, W. L. G. (2007). School Functioning in Early Adolescence: Gender-Linked Responses to Peer Victimization. Journal of Educational Psychology, 99(4), 683-699. https://doi.org/10.1037/00220663.99.4.683

Houbre, B., Tarquinio, C., \& Lanfranchi, J.-B. (2010). Expression of self-concept and adjustment against repeated aggressions : the case of a longitudinal study on school bullying. European Journal of $P$, 25(1), 105-123. https://doi.org/10.1007/s10212-0090005-x

Indonesia, UNICEF. (2015). Laporan Tahunan Indonesia 2015.

Jenkins, L. N. (2015). Indirect Effects in the Peer Victimization-Academic Achievement Relation: The Role of Academic Self-Concept and Gender. Psychology in the Schools, 52(3), 153178. https://doi.org/10.1002/pits

Juvonen, J., Wang, Y., \& Espinoza, G. (2011). Bullying experiences and compromised academic performance across middle school grades. Journal of Early Adolescence, 31(1), 152-173. https://doi.org/10.1177/0272431610379 415

Kaukiainen, A., Salmivalli, C., Lagerspetz, K., Tamminen, M., Vauras, M., Mäki, H., \& Poskiparta, E. (2002). Learning difficulties, social intelligence, and selfconcept: Connections to bully-victim problems. Scandinavian Journal of Psychology, 43(3), 269-278. https://doi.org/10.1111/14679450.00295

Kibriya, S., Xu, Z. P., \& Zhang, Y. (2016). The negative consequences of school bullying on academic performance and mitigation through female teacher participation: evidence from Ghana. 
Applied Economics, O(0), 1-11. https://doi.org/10.1080/00036846.2016. 1240350

Lösch, T., Lüdtke, O., Robitzsch, A., Kelava, A., Nagengast, B., \& Trautwein, U. (2017). A Well-Rounded View: Using an Interpersonal Approach to Predict Achievement by Academic SelfConcept and Peer Ratings of Competence. Contemporary Educational Psychology. https://doi.org/10.1016/j.cedpsych.2017. 07.003

Ma, L., Phelps, E., Lerner, J. V, Lerner, R. M., \& Phelps, E. (2009). Academic Competence for Adolescents Who Bully and Who Are Bullied. The Journal of Early Adolescence, 29 Number. http://doi.org/10.1177/02724316093326 67

Marsh, H. W., \& Martin, A. J. (2011). Academic self-concept and academic achievement: Relations and causal ordering. British Journal of Educational Psychology, 81(1), 59-77. https://doi.org/10.1348/000709910X503 501

Matovu, M. (2012). Academic Self-Concept and Academic Achievement among University Students. International Online Journal of Educational Sciences, 4(1), 107-116.

Permenkes. (2014). Peraturan Menteri Kesehatan Republik Indonesia Nomor 75 Tahun 2014 Tentang Pusat Kesehatan Masyarakat. Jakarta.

Raskauskas, J. (2010). Multiple peer victimization among elementary school students: relations with social-emotional problems. Social Psychology of Education, 18(2), 523-539. https://doi.org/10.1007/s11218-0109124-0
Samiroh, S., \& Muslimin, Z. (2016). Hubungan Antara Konsep Diri Akademik dan Perilaku Menyontek pada Siswa- Siswi Mas Simbangkulon Buaran Pekalongan. Psikis : Jurnal Psikologi Islami, 1(2), 67-77. Retrieved from http://jurnal.radenfatah.ac.id/index.php/ psikis/article/view/569

Sriati, A. (2010). Pengaruh Konsep Diri dan Motivasi Berprestasi Terhadap Prestasi Akademik Remaja Akhir.

Wilson, H. E., Siegle, D., Mccoach, D. B., Little, C. A., Reis, S. M., Little, C. A., \& Reis, S. M. (2014). Gifted Child Quarterly. Gifted Child Quarterly, 58(2),

111-126. https://doi.org/10.1177/0016986214522 858

Wolke, D., \& Lereya, S. T. (2015). Long-term effects of bullying. British Medical Journal, $\quad 100, \quad 879-885$. http://doi.org/10.1136/archdischild2014-306667

Wu, W., Luu, S., \& Luh, D. (2016). Defending behaviors, bullying roles, and their associations with mental health in junior high school students : a population- based study. BMC Public Health, (110), $1-11$. http://doi.org/10.1186/s12889-0163721-6 